\title{
Title:
}

\section{Curcumin and curcumoids: hepatoprotection or hepatotoxicity?}

\section{Authors:}

Miguel Fernández Bermejo, Alberto Masa Caballero, Ángela Lozano Lozano

DOI: $10.17235 /$ reed.2022.8588/2022

Link: PubMed (Epub ahead of print)

Please cite this article as:

Fernández Bermejo Miguel , Masa Caballero Alberto, Lozano Lozano Ángela. Curcumin and curcumoids: hepatoprotection or hepatotoxicity?. Rev Esp Enferm Dig 2022. doi: 10.17235/reed.2022.8588/2022.

This is a PDF file of an unedited manuscript that has been accepted for publication. As a service to our customers we are providing this early version of the manuscript. The manuscript will undergo copyediting, typesetting, and review of the resulting proof before it is published in its final form. Please note that during the production process errors may be discovered which could affect the content, and all legal disclaimers that apply to the journal pertain. 


\section{Carta 8588 inglés}

\section{Curcumin and curcumoids: hepatoprotection or hepatotoxicity?}

Miguel Fernández Bermejo, Alberto Masa Caballero, and Ángela Lozano Lozano Department of Digestive Diseases. Hospital Universitario de Cáceres. Cáceres, Spain

Correspondence:

Miguel Fernández Bermejo

mfbermejo@gmail.com

Conflicts of interest: the authors declare no conflicts of interest.

Keywords: Curcumin. Hepatotoxicity.

Dear Editor,

Curcumin (Curcuma longa) and curcumin analogues are plant-based drugs used because of their possible antioxidant, anti-inflammatory and "hepatoprotective" properties (1).

We present the case of a 44-year-old female who presented to the emergency room due to asthenia and progressive jaundice for the last two weeks. Laboratory findings showed moderate conjugated hyperbilirubinemia, along with acute hypertransaminasemia and cholestasis. Those tests were normal six months before (Table 1). Abdominal ultrasound was normal, whereas laboratory work ruled out hepatotropic virus-related and auto-immune hepatitis. The patient had been taking magnesium and curcumin supplements with curcumoids for two weeks due to joint pain. Withdrawal of nutritional supplements led to clinical and biochemical normalization over the next six months.

Curcumin ingestion alone has low bioavailability, with rapid metabolism and rapid elimination. Several agents have been tested, mainly blocking the metabolic pathway of curcumin, in order to increase its bioavailability $(2,3)$, which could increase its toxic effects. Clinical data on the efficacy of curcumin as a hepatoprotective drug are limited 
and conflicting, with growing concern for formulations that may potentially increase curcumin bioavailability (4).

\section{REFERENCES}

1. Pulido-Moran M, Moreno-Fernandez J, Ramirez-Tortosa C, et al. Curcumin and Health. Molecules 2016;21(3):264. DOI: 10.3390/molecules21030264

2. Hewlings $S$, Kalman D. Curcumin: a review of its effects on human health. Foods 2017;6(10):92. DOI: 10.3390/foods6100092

3. Sohn SI, Priya A, Balasubramaniam B, et al. Pandian biomedical applications and bioavailability of curcumin - An updated overview. S. Pharmaceutics 2021;13(12):2102. DOI: $10.3390 /$ pharmaceutics13122102

4. Lombardi N, Crescioli G, Maggini V, et al. Acute liver injury following turmeric use in Tuscany: An analysis of the Italian Phytovigilance database and systematic review of case reports. Br J Clin Pharmacol 2021;87(3):741-53. DOI: 10.1111/bcp.14460

Table 1. Serological evolution 
ENFERMEDADES DIGESTIVAS

The Spanish Journal of Gastroenterology

\begin{tabular}{|c|c|c|c|c|c|c|}
\hline & $\begin{array}{c}6 \text { months } \\
\text { before }\end{array}$ & $\begin{array}{c}\text { Emergency } \\
\text { room }\end{array}$ & $\begin{array}{c}7 \\
\text { days } \\
\text { after }\end{array}$ & $\begin{array}{c}15 \text { days } \\
\text { after }\end{array}$ & $\begin{array}{c}3 \text { months } \\
\text { after }\end{array}$ & $\begin{array}{c}6 \text { months } \\
\text { after }\end{array}$ \\
\hline $\begin{array}{l}\text { GOT } \\
(\mathrm{U} / \mathrm{L})\end{array}$ & 22 & 2008 & 994 & 371 & 41 & 21 \\
\hline $\begin{array}{l}\text { GPT } \\
(\mathrm{U} / \mathrm{L})\end{array}$ & 18 & 2383 & 1493 & 786 & 47 & 18 \\
\hline $\begin{array}{l}\text { GGT } \\
(U / L)\end{array}$ & 20 & 571 & - & - & 28 & 15 \\
\hline $\begin{array}{l}\text { ALP } \\
(U / L)\end{array}$ & 46 & 604 & - & - & 58 & 45 \\
\hline $\begin{array}{c}\text { TBil } \\
(\mathrm{mg} / \mathrm{dL})\end{array}$ & 0.66 & 8.43 & 4.98 & 2.69 & 0.95 & 0.87 \\
\hline $\begin{array}{c}\text { DBil } \\
(\mathrm{mg} / \mathrm{dL})\end{array}$ & - & 8.02 & 3.90 & 2.26 & - & \\
\hline $\begin{array}{l}\text { PA } \\
(\%)\end{array}$ & 91 & 88 & 87 & 87 & 100 & 100 \\
\hline INR & 1.06 & 1.1 & 1.1 & 1.1 & 1 & 0.97 \\
\hline
\end{tabular}

GOT: glutamic oxaloacetic transaminase; GPT: glutamate pyruvate transaminase; GGT: gamma-glutamyl transferase; ALP: alkaline phosphatase; TBil: total bilirubin; DBil: direct bilirubin; PA: prothrombin activity; INR: international normalized ratio. 